\title{
EFFECTS OF LEAD PHYTOTOXICITY ON DIFFERENT PEANUT VARIETIES GERMINATION AND SEEDLING GROWTH
}

\author{
KAYA, A. R. \\ Department of Field Crops, Agricultural Faculty, Kahramanmaras Sutcu Imam University, \\ Kahramanmaraş, Turkey \\ (e-mail: alirahmikaya@ksu.edu.tr; phone: +90-344-300-2164; fax: +90-344-300-2002) \\ (Received $3^{\text {rd }}$ May 2020; accepted $13^{\text {th }}$ Aug 2020)
}

\begin{abstract}
Lead is a highly toxic environmental pollutant for plants and other living organisms, including humans. To determine the effects of lead phytotoxicity on germination and seedling growth of 10 peanut (Arachis hypogaea L.) varieties, a study was conducted to screen the influence of different lead nitrate $\left(\mathrm{PbNO}_{3}\right)_{2}$ doses in May 2016 at $25{ }^{\circ} \mathrm{C}( \pm 2)$ in the Department of Field Crops Laboratory, Faculty of Agriculture, Kahramanmaras Sutcu İmam University. The treatment was carried out according to the completely randomized plot experimental design with three replications. In the experiment, two pieces of filter paper were placed in each of the 120 sterile petri dishes and then, 25 seeds of each varieties were placed to germinate. After 14 days, some main germination and seedling growth parameters were observed. All the characteristics studied were affected differently by lead doses according to of varieties. Peanut varieties were observed to react differently to lead concentrations due to their different genotypic structure, and some did not have a significant effect on lead doses. Overall, it can be concluded that lead is privative, but plants employ mechanisms to resist it. Thus, further research should be carried out to select and develop cultivars that have superior tolerance to $\mathrm{Pb}$.
\end{abstract}

Keywords: germination, lead nitrate $\left(\mathrm{Pb}\left(\mathrm{NO}_{3}\right)_{2}\right)$, peanut (Arachis hypogaea L.), seed, seedling vigor index, toxicity

\section{Introduction}

Peanut (earthnut, groundnut, ground bean) belongs to the Arachis genus, an annual, soil enriching, self-pollinated legume, it is an oilseed, and a member of the Leguminosae family and the Papilionaceae subfamily. It is widely grown in the tropics and temperate regions in six continents between latitudes $40^{\circ} \mathrm{N}$ and $40^{\circ} \mathrm{S}$, from warm temperate to equatorial climates (Konlan et al., 2013; Sharma and Bhatnagar-Mathur, 2006). There are numerous confinements to the productivity of the peanut crop that result in enormous economic losses. Traditional plant breeding practices and methodologies have not been successful in conferring resistance against different biotic and abiotic stresses owing to species restrictions in the natural system. Although it is not sufficiently successful, there is always a need to determine the resistance to abiotic stresses, especially in varieties developed as yield and resistant to certain diseases. Negative effects of non-living factors on living organisms in a given environment can be defined as abiotic stress. There are various types of abiotic stresses such as drought, over-watering, extreme temperatures (cold, frost and heat), salinity and mineral toxicity. Abiotic stresses are the main causes of poor plant growth and reduced plant production in the world (Onaga and Wydra, 2016). Minerals consist of heavy metals that are toxic even to a very low concentrations for both plants and animals. Some heavy metals, such as arsenic, cadmium, mercury, lead and selenium, do not perform any physiological functions known in plants and are called non-essential metals. These metals generally have negative effects on seed germination, plant growth, development, yield and seed quality depending on the plant species. Other minerals such as ferrum, zinc, cobalt, 
copper, manganese, molybdenum and nickel are essential elements for the normal growth and metabolism of plants. When the concentrations of these essential elements exceed the optimum level, it may cause poisoning (Mani and Sankaranarayanan, 2018). Environmental conditions' changes influence the biological and physiological reactions of plants. For general growth and development, plants need a variety of mineral elements. These minerals are existing in the soil and absorbed by the roots, a great many of them are transferred to the shoots and then distributed to various organs and tissues of the plant depending on their requirements (Mani and Sankaranarayanan, 2018).

Lead ranks second among all the hazardous heavy metals (Kumar et al., 2012) and is the most common heavy metal pollutant in the environment, according to the Environmental Protection Agency (EPA) (Lamhamdi et al., 2011). Lead inhibits the activity of many enzymes, disrupts mineral nutrition and water balance, alters hormonal status and affects membrane structure and permeability. Lead reduces the photosynthetic rate of plants, thereby limiting plant growth by disrupting the chloroplast infrastructure, reducing chlorophyll synthesis, inhibiting electron transfer, and inhibiting the activities of the Calvin cycle enzymes (Sengar et al., 2008). Lead toxicity causes inhibition of ATP production, lipid peroxidation and DNA damage. In addition, lead strongly inhibits seed germination, root growth, seedling growth, plant growth, sweating, chlorophyll production and water and protein content (Pourrut et al., 2011).

This study deals with the effects abiotic stress due to lead nitrate toxicity concentrations on germination and seedling growth parameters of Arachis hypogaea L., and to demonstrate the differences among these 10 varieties.

\section{Material and methods}

The study was carried out at $25^{\circ} \mathrm{C}( \pm 2)$ in the laboratory of Department of Field Crops, Faculty of Agriculture, Kahramanmaras Sutcu Imam University in May 2016 in Turkey.

In this study, which investigated how lead's phytotoxicity affects germination and subsequent seedling development, 10 (Arığlu-2003, Batem-5025, Florispan, Georgia Green, Halisbey, NC-V-II, NC-7, Osmaniye-2005, Sultan and Wilson) varieties of peanuts obtained from Çukurova University Faculty of Agriculture, Department of Field Crops and Osmaniye Agricultural Research Institute were used as materials. The cultivars used in this study, are the major peanut varieties have been registered in Turkey. In addition, all of the varieties planted in Turkey confectionary Virginia type varieties. The most common planted variety is NC-7. Also; There are also local seeds in the form of unregistered farmer populations such as Anamur, Osmaniye, Aydin (Kadiroğlu, 2008).

In this study, healthy and homogenous seeds of 10 peanut varieties were sterilized with 5\% NaOCI (sodium hypochlorite) solution for $5 \mathrm{~min}$ and then rinsed with tap water. In the study, lead nitrate $\mathrm{Pb}\left(\mathrm{NO}_{3}\right)_{2}$ which was used as stress factor was prepared in four different doses as $0,100,200$ and $400 \mathrm{mg} \mathrm{L}^{-1}$, respectively. In the study, 25 seeds of each variety were sown on to germinate for 14 days in 120 sterile petri dishes, each with two filter papers. During sowing, $20 \mathrm{ml}$ of all concentrations prepared separately were added to each petri dish. The same amount of tap water was added to the petri dishes, which were evaluated as controls. After two days, $15 \mathrm{ml}$ of these solutions were added to each petri dish six times at two-day intervals. The petri dish's 
lids were closed and placed in growth booths, setting germination rates at the same time each day. In order to assess germination of the seed, seeds with a root formation of $1 \mathrm{~mm}$ were considered germinated seeds (Munzuroglu and Geckil, 2002). Germination test was terminated at the end of 14 days when the cotyledon leaves emerged completely. In the study, some basic germination and seedling parameters such as germination percentage, germination index, radicle length, plumule length, seedling length, radicle fresh weight, plumule fresh weight, seedling fresh weight, radicle dry weight, plumule dry weight, seedling dry weight, seedling vigor index and germinated seed number were observed. The germination rate was found by dividing the germinated seeds by the total number of seeds and then multiplying by 100 (Maquire, 1962).

$$
\text { Germination percentage }=\frac{\text { Germinated seeds number }}{\text { Total seeds number }} x 100
$$

Germination index $=\sum \mathrm{Gt} / \mathrm{Dt}$, Gt is the number of germinated seeds in t days; $\mathrm{Dt}$ is the number of corresponding germination days (Ertekin et al., 2011).

The length of the seedling was found by measuring the length of the radicle and plumule separately and then adding both lengths (AOSA, 1984).

After measurements of the fresh samples, the samples were kept for $24 \mathrm{~h}$ in an oven set at $78^{\circ} \mathrm{C}$, and then analyses of the dry samples were performed (AOSA, 1984).

Seedling vigor index was found by multiplying seedling length by germination percentage (Abdul-Baki and Anderson, 1973; AOSA, 1984).

\section{Seedling vigor index $=$ Seedling length $x$ Germination percentage}

\section{Statistical analysis of data}

All data obtained from the study were processed by SAS (v. 9.0, 2002) statistical package. The analysis of variance (ANOVA) was performed according to the Completely Randomized Experimental Design procedures at significant levels of $\mathrm{p}<0.01$ or $\mathrm{P}<0.05$. To detect the significant differences $(\mathrm{p}<0.01$ or $\mathrm{p}<0.05)$ of variables, Least Significant Difference (LSD), a multiple comparison test, was performed. Additionally, the Pearson Correlation analysis was processed to determine the relationship among the observed parameters.

\section{Results and discussion}

\section{Germination percentage (\%)}

In terms of tolerance to increasing lead doses, when the varieties were examined, statistically significant $(\mathrm{P}<0.01)$ differences were found among the varieties. The highest germination rate $(100 \%)$ was obtained from Batem-5025 variety, while the lowest (87.67\%) was obtained from Osmaniye-2005 variety (Table 1). Differences among the lead doses in terms of their effects on germination rates were found to be insignificant $(\mathrm{P}>0.05)$ and it was determined that germination rates ranged between 94.67\% and $98.27 \%$ (Table 1). As shown in Table 1, lead doses had different effects on seed germination rates of peanut varieties. It was found that peanut varieties react differently to lead levels due to genotypic differences. 
Table 1. The means and LSD groups of GP, GI, RL, PL, SL, RFW, PFW properties of Arachis hypogaea L. varieties

\begin{tabular}{|c|c|c|c|c|c|c|c|c|c|c|c|c|c|c|c|}
\hline Varieties & $\begin{array}{l}\text { Doses } \\
\left(\mathrm{g} \mathrm{L}^{-1}\right) \\
\end{array}$ & $\begin{array}{l}\text { GP } \\
(\%)\end{array}$ & $* *$ & GI & $* *$ & $\begin{array}{c}\mathbf{R L} \\
(\mathbf{c m})\end{array}$ & $* ; * *$ & $\begin{array}{c}\text { PL } \\
(\mathbf{c m})\end{array}$ & $* *$ & $\begin{array}{c}\text { SL } \\
(\mathrm{cm})\end{array}$ & $* ; * *$ & $\begin{array}{c}\text { RFW } \\
(\mathrm{g})\end{array}$ & $* ; * *$ & $\begin{array}{c}\text { PFW } \\
(\mathrm{g})\end{array}$ & $* ; * *$ \\
\hline \multirow{5}{*}{ Arıŏglu-2003 } & Control & 97.3 & & 11.11 & & 3.95 & b-g & 3.09 & & 7.04 & a-d & 2.58 & b-g & 24.74 & $a-c$ \\
\hline & 100 & 100.0 & & 11.67 & & 4.14 & $b-f$ & 2.96 & & 7.10 & $a-d$ & 2.56 & b-g & 24.77 & $a-c$ \\
\hline & 200 & 97.3 & & 11.22 & & 3.80 & b-g & 3.12 & & 6.92 & $a-d$ & 2.72 & $b-f$ & 24.47 & $a-c$ \\
\hline & 400 & 94.7 & & 10.64 & & 3.35 & c-g & 3.36 & & 6.71 & $a-e$ & 1.72 & e-h & 22.23 & b-d \\
\hline & Mean & 97.3 & $\mathbf{A B}$ & 11.16 & AB & 3.81 & $\mathbf{C}$ & 3.13 & $\mathbf{A B}$ & 6.94 & CDE & 2.40 & B & 24.05 & B \\
\hline \multirow{5}{*}{ Batem-5025 } & Control & 100.0 & & 12.00 & & 5.61 & $a-c$ & 3.71 & & 9.32 & $\mathrm{a}$ & 1.75 & e-h & 15.62 & e-h \\
\hline & 100 & 100.0 & & 11.97 & & 6.08 & $a b$ & 3.47 & & 9.55 & $\mathrm{a}$ & 1.87 & e-h & 16.99 & $d-f$ \\
\hline & 200 & 100.0 & & 11.19 & & 5.23 & $a-c$ & 3.07 & & 8.30 & $a b$ & 2.13 & d-h & 21.14 & $\mathrm{~cd}$ \\
\hline & 400 & 100.0 & & 11.89 & & 4.75 & $a-d$ & 3.11 & & 7.86 & $a-c$ & 2.28 & c-h & 19.29 & c-e \\
\hline & Mean & 100.0 & $\mathbf{A}$ & 11.76 & $\mathbf{A}$ & 5.42 & $\mathbf{A}$ & 3.34 & $\mathbf{A}$ & 8.75 & $\mathbf{A}$ & 2.01 & BCD & 18.26 & D \\
\hline \multirow{5}{*}{ Florispan } & Control & 96.0 & & 10.92 & & 3.72 & c-g & 2.13 & & 5.85 & c-e & 1.61 & $\mathrm{f}-\mathrm{h}$ & 11.60 & $\mathrm{~h}$ \\
\hline & 100 & 100.0 & & 11.93 & & 5.31 & $a-c$ & 2.70 & & 8.01 & $a b$ & 2.00 & $e-h$ & 13.01 & $f-h$ \\
\hline & 200 & 98.7 & & 12.11 & & 5.66 & $a-c$ & 2.97 & & 8.64 & $\mathrm{a}$ & 2.08 & $e-h$ & 12.70 & gh \\
\hline & 400 & 98.7 & & 11.83 & & 5.45 & $a-c$ & 3.45 & & 8.90 & $\mathrm{a}$ & 1.93 & e-h & 13.39 & f-h \\
\hline & Mean & 98.3 & $\mathbf{A B}$ & \begin{tabular}{|l|}
11.70 \\
\end{tabular} & $\mathbf{A}$ & 5.04 & $\mathbf{A}$ & 2.81 & BC & 7.85 & $\mathbf{A B C}$ & 1.91 & CD & 12.67 & $\mathbf{E}$ \\
\hline \multirow{5}{*}{ Georgia Green } & Control & 94.7 & & 11.22 & & 4.27 & b-e & 2.50 & & 6.77 & $a-d$ & 1.65 & f-h & 15.02 & f-h \\
\hline & 100 & 100.0 & & 12.00 & & 6.52 & $\mathrm{a}$ & 2.34 & & 8.86 & $\mathrm{a}$ & 1.69 & f-h & 13.64 & $e-g$ \\
\hline & 200 & 100.0 & & 12.08 & & 3.83 & b-g & 2.31 & & 6.15 & c-e & 1.40 & $\mathrm{~h}$ & 13.39 & $f-h$ \\
\hline & 400 & 98.7 & & 11.94 & & 5.09 & $a-c$ & 3.07 & & 8.17 & $\mathrm{ab}$ & 1.68 & f-h & 15.87 & f-h \\
\hline & Mean & 98.3 & $\mathbf{A B}$ & 11.81 & $\mathbf{A}$ & 4.93 & $\mathbf{A B}$ & 2.56 & CD & 7.49 & BCD & 1.61 & D & 14.48 & $\mathbf{E}$ \\
\hline \multirow{5}{*}{ Halisbey } & Control & 98.7 & & 10.39 & & 2.11 & $\mathrm{fg}$ & 2.22 & & 4.33 & e-g & 1.80 & e-h & 24.31 & $\mathrm{bc}$ \\
\hline & 100 & 98.7 & & 10.22 & & 2.23 & fg & 2.37 & & 4.60 & d-g & 2.34 & $\mathrm{c}-\mathrm{g}$ & 25.39 & $a b$ \\
\hline & 200 & 100.0 & & 10.42 & & 1.78 & $\mathrm{~g}$ & 2.00 & & 3.77 & $\mathrm{fg}$ & 1.58 & $\mathrm{gh}$ & 23.21 & $b c$ \\
\hline & 400 & 100.0 & & 10.47 & & 2.77 & $\mathrm{fg}$ & 2.07 & & 4.85 & $\mathrm{~d}-\mathrm{g}$ & 1.83 & e-h & 24.19 & $\mathrm{bc}$ \\
\hline & Mean & 99.3 & AB & \begin{tabular}{|l|}
10.38 \\
\end{tabular} & C & 2.22 & $\mathbf{E}$ & 2.16 & DE & 4.39 & $\mathbf{F}$ & 1.89 & CD & 24.27 & B \\
\hline \multirow{5}{*}{ NC-V-II } & Control & 93.3 & & 8.92 & & 2.99 & e-g & 2.61 & & 5.61 & $\mathrm{de}$ & 1.83 & e-h & 25.29 & $a b$ \\
\hline & 100 & 98.7 & & 10.17 & & 3.42 & $\mathrm{c}-\mathrm{g}$ & 3.82 & & 7.24 & $a-c$ & 1.85 & e-h & 28.33 & $\mathrm{a}$ \\
\hline & 200 & 94.7 & & 9.22 & & 3.01 & e-g & 3.66 & & 6.67 & b-e & 1.99 & e-h & 26.61 & $a b$ \\
\hline & 400 & 100.0 & & 10.50 & & 3.87 & b-g & 3.25 & & 7.12 & $a-c$ & 3.11 & $\mathrm{bc}$ & 26.28 & $a b$ \\
\hline & Mean & 96.7 & $\mathbf{A B}$ & \begin{tabular}{|l|}
9.70 \\
\end{tabular} & DE & 3.32 & CD & 3.34 & $\mathbf{A}$ & 6.66 & DE & 2.19 & BC & 26.63 & $\mathbf{A}$ \\
\hline \multirow{5}{*}{ NC-7 } & Control & 86.7 & & 9.53 & & 2.06 & $\mathrm{fg}$ & 2.93 & & 4.99 & d-f & 2.15 & d-h & 20.04 & $\mathrm{~cd}$ \\
\hline & 100 & 97.3 & & & & 3.60 & $\mathrm{c}-\mathrm{g}$ & 3.11 & & 6.71 & $b-e$ & 3.60 & $\mathrm{~b}$ & 12.01 & $\mathrm{~h}$ \\
\hline & 200 & 100.0 & & 10.75 & & 4.65 & $b-d$ & 2.71 & & 7.36 & $a-c$ & 2.99 & $\mathrm{bc}$ & 25.52 & $a b$ \\
\hline & 400 & 96.0 & & 10.50 & & 4.83 & $\mathrm{a}-\mathrm{c}$ & 3.17 & & 8.00 & $\mathrm{ab}$ & 2.91 & b-d & 26.65 & $a b$ \\
\hline & Mean & 95.0 & B & 10.38 & C & 3.78 & C & 2.98 & $\mathbf{A B C}$ & 6.77 & DE & 2.91 & A & 21.06 & C \\
\hline \multirow{5}{*}{$\begin{array}{l}\text { Osmaniye- } \\
2005\end{array}$} & Control & 80.0 & & 8.67 & & 3.62 & c-g & 2.20 & & 5.82 & de & 2.70 & b-f & 25.37 & $a b$ \\
\hline & 100 & 92.0 & & 9.72 & & 3.45 & $\mathrm{c}-\mathrm{g}$ & 1.73 & & 5.18 & de & 2.52 & $c-g$ & 26.12 & $a b$ \\
\hline & 200 & 90.7 & & 9.68 & & 4.28 & b-d & 2.12 & & 6.40 & c-e & 2.98 & $\mathrm{bc}$ & 26.44 & $a b$ \\
\hline & 400 & 88.0 & & 9.92 & & 5.11 & $a-c$ & 2.03 & & 7.15 & $a-c$ & 4.18 & $\mathrm{a}$ & 26.63 & $a b$ \\
\hline & Mean & 87.7 & $\mathrm{C}$ & 9.50 & $\mathbf{E}$ & 4.11 & BC & 2.02 & $\mathbf{E}$ & 6.14 & $\mathbf{E}$ & 3.10 & A & 26.14 & $\mathbf{A}$ \\
\hline \multirow{5}{*}{ Sultan } & Control & 100.0 & & 10.47 & & 2.98 & $\mathrm{fg}$ & 2.29 & & 5.27 & de & 2.02 & e-h & 26.10 & $a b$ \\
\hline & 100 & 100.0 & & 10.11 & & 1.83 & $\mathrm{~g}$ & 1.86 & & 3.69 & $\mathrm{~g}$ & 1.41 & $\mathrm{~h}$ & 25.39 & $a b$ \\
\hline & 200 & 96.0 & & 9.86 & & 3.39 & $c-g$ & 2.24 & & 5.62 & de & 2.02 & e-h & 26.94 & $a b$ \\
\hline & 400 & 98.7 & & 10.69 & & 3.15 & d-g & 2.59 & & 5.74 & de & 2.05 & e-h & 28.26 & $\mathrm{a}$ \\
\hline & Mean & $\begin{array}{l}98.7 \\
\end{array}$ & $\mathbf{A B}$ & \begin{tabular}{|l|l|}
10.28 \\
\end{tabular} & CD & 2.83 & DE & 2.25 & DE & 5.08 & $\mathbf{F}$ & 1.87 & CD & 26.67 & $\mathbf{A}$ \\
\hline \multirow{5}{*}{ Wilson } & Control & 100.0 & & 11.67 & & 5.64 & $a-c$ & 2.85 & & 8.49 & $\mathrm{a}$ & 2.24 & d-h & 22.30 & $\mathrm{bc}$ \\
\hline & 100 & 96.0 & & 9.22 & & 4.20 & b-e & 2.66 & & 6.87 & $a-d$ & 1.95 & e-h & 21.07 & $\mathrm{~cd}$ \\
\hline & 200 & 97.3 & & 11.22 & & 6.37 & $\mathrm{a}$ & 3.13 & & 9.50 & $\mathrm{a}$ & 2.71 & $b-f$ & 25.21 & $a b$ \\
\hline & 400 & 98.7 & & 11.06 & & 4.27 & b-e & 3.35 & & 7.63 & $a-c$ & 2.73 & b-e & 28.32 & $\mathrm{a}$ \\
\hline & Mean & 98.0 & $\mathbf{A B}$ & 10.79 & BC & 5.12 & $\mathbf{A}$ & 3.00 & ABC & 8.12 & ABC & 2.41 & B & 24.22 & B \\
\hline \multicolumn{2}{|c|}{ LSD (0.05) for V } & 4.46 & & 0.66 & & 0.85 & & 0.45 & & 0.96 & & 0.421 & & 1.849 & \\
\hline \multirow{2}{*}{\multicolumn{2}{|c|}{$\begin{array}{c}\operatorname{LSD}(0.05) \text { for } \operatorname{LD} \\
\operatorname{LSD}(0.05) \text { for } V \times x D\end{array}$}} & 2.82 & & 0.42 & & 0.54 & & 0.29 & & 0.61 & & 0.266 & & 1.170 & \\
\hline & & 15.46 & & 2.29 & & 2.96 & & 1.57 & & 3.33 & & 1.457 & & 6.406 & \\
\hline \multicolumn{2}{|c|}{$\mathrm{CV}(\%)$} & 5.66 & & 7.55 & & 25.87 & & 20.25 & & 17.34 & & 23.212 & & 10.415 & \\
\hline
\end{tabular}

GP: Germination Percentage, GI: Gemination Index, RL: Radicle Length, PL: Plumule Length, SL: Seedling Length, RFW: Radicle Fresh Weight, PFW: Plumule Fresh Weight, V: Varieties, LD: Lead doses

*The mean in the same column, expressed in lowercase and indicated with different letters, is statistically different from each other within the $\mathrm{P} \leq 0.05$ error limits according to LSD test

**The mean in the same column, expressed in capital and indicated with different letters, is statistically different from each other within the $\mathrm{P} \leq 0.05$ error limits according to LSD test 


\section{Germination index}

It was seen that there were statistically significant $(\mathrm{P}<0.01)$ variations among the varieties in terms of germination indexes. The highest $(11.81,11.77$ and 11.70, respectively) germination indexes were determined from Georgia Green, Batem-5025 and Florispan, while the lowest (9.50) was found in Osmaniye-2005. No significant $(\mathrm{P}>0.05)$ differences were found among the lead doses in terms of their effects on germination indexes (Table 1).

\section{Radicle length $(\mathrm{cm})$}

As can be seen from Table 1, in terms of radicle lengths, statistically significant differences $(\mathrm{P}<0.01)$ were found among the varieties. The highest radicle lengths were measured from Batem-5025, Wilson and Florispan $(5.42,5.12$, and $5.04 \mathrm{~cm}$ ) varieties, respectively, while the lowest $(2.22 \mathrm{~cm})$ was observed from Halisbey varieties. The differences between lead doses were found to be insignificant $(p>0.05)$ in terms of their effect on radicle lengths and it was determined that the radicle lengths obtained from different doses ranged between 3.69 and $4.27 \mathrm{~cm}$ (Table 1). Due to the different reactions of the varieties to the increased lead doses, the effect of variety and dose interaction on radicle lengths was found to be statistically significant $(\mathrm{p}<0.05)$. The highest radicle lengths $(6.52$ and $6.37 \mathrm{~cm})$ were measured from Georgia Green and Wilson varieties at 100 and $200 \mathrm{mg} \mathrm{Pb}\left(\mathrm{NO}_{3}\right)_{2} \mathrm{~L}^{-1}$ doses, while the lowest (1.78 and $1.83 \mathrm{~cm}$ ) were observed in Halisbey and Sultan varieties at doses of 200 and $100 \mathrm{mg}$ $\mathrm{Pb}\left(\mathrm{NO}_{3}\right)_{2} \mathrm{~L}^{-1}$ (Table 1; Fig. 1).

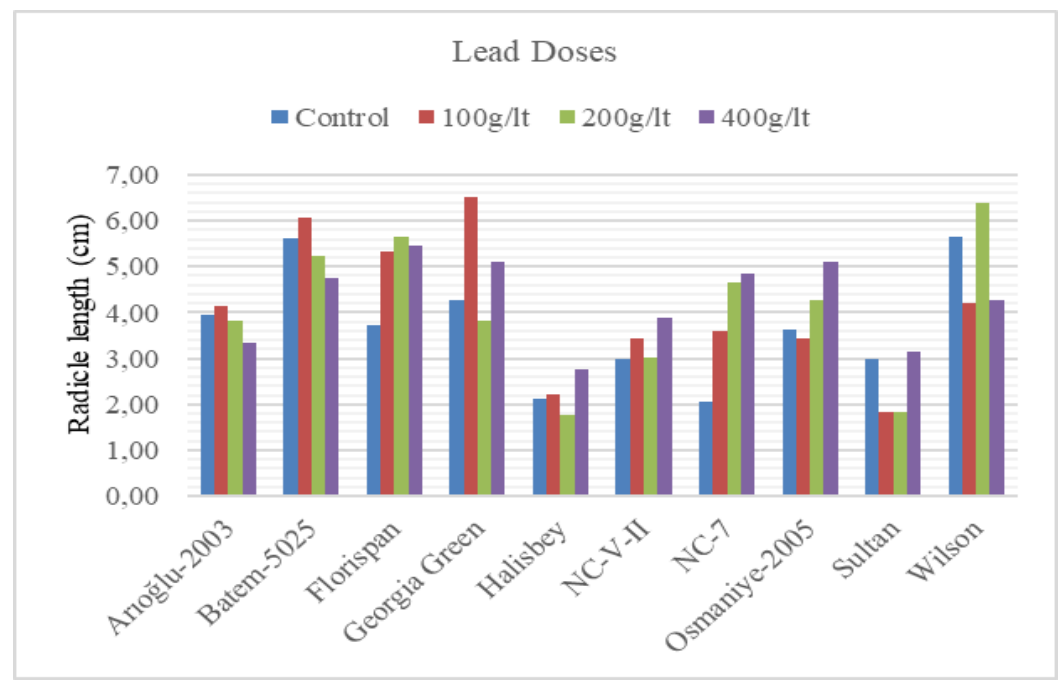

Figure 1. The interaction of Arachis hypogaea L. varieties' radicle length

\section{Plumule length (cm)}

In the experiment, it was found that there were statistically significant differences $(\mathrm{P}<0.01)$ among the varieties in terms of plumule lengths. The highest plumule lengths were seen in Batem-5025 $(3.34 \mathrm{~cm})$ and $\mathrm{NC}-\mathrm{V}$-II $(3.34 \mathrm{~cm})$ varieties, while the lowest was measured from Osmaniye-2005 variety as $2.02 \mathrm{~cm}$. Differences among lead doses were found to be insignificant $(\mathrm{P}>0.05)$ in terms of their effects on plumule lengths, and plumule lengths were determined to vary between 2.65 and $2.95 \mathrm{~cm}$ (Table 1). 


\section{Seedling length (cm)}

From Table 1, it was found that there was a statistically significant $(\mathrm{P}<0.01)$ variation among the varieties in terms of seedling lengths. The highest seedling length was observed in Batem-5025 variety as $8.76 \mathrm{~cm}$, while the lowest seedling lengths were seen in Halisbey $(4.39 \mathrm{~cm})$ and Sultan $(5.08 \mathrm{~cm})$ varieties. As a result of the study, it was found that there were statistically significant $(\mathrm{P}<0.05)$ differences among lead doses in terms of their effects on seedling lengths. The highest seedling length was measured as $7.21 \mathrm{~cm}$ at $400 \mathrm{mg} \mathrm{Pb}\left(\mathrm{NO}_{3}\right)_{2} \mathrm{~L}^{-1}$ dose, while the lowest was determined as $6.35 \mathrm{~cm}$ at the control dose (Table 1). The effect of variety and dose interaction on seedling lengths was statistically significant $(\mathrm{P}<0.05)$ due to the different responses of varieties to lead doses. The lowest seedling length of $3.69 \mathrm{~cm}$ was observed in Sultan variety at $100 \mathrm{mg} \mathrm{PB}\left(\mathrm{NO}_{3}\right)_{2} \mathrm{~L}^{-1}$ doses (Table 1; Fig. 2).

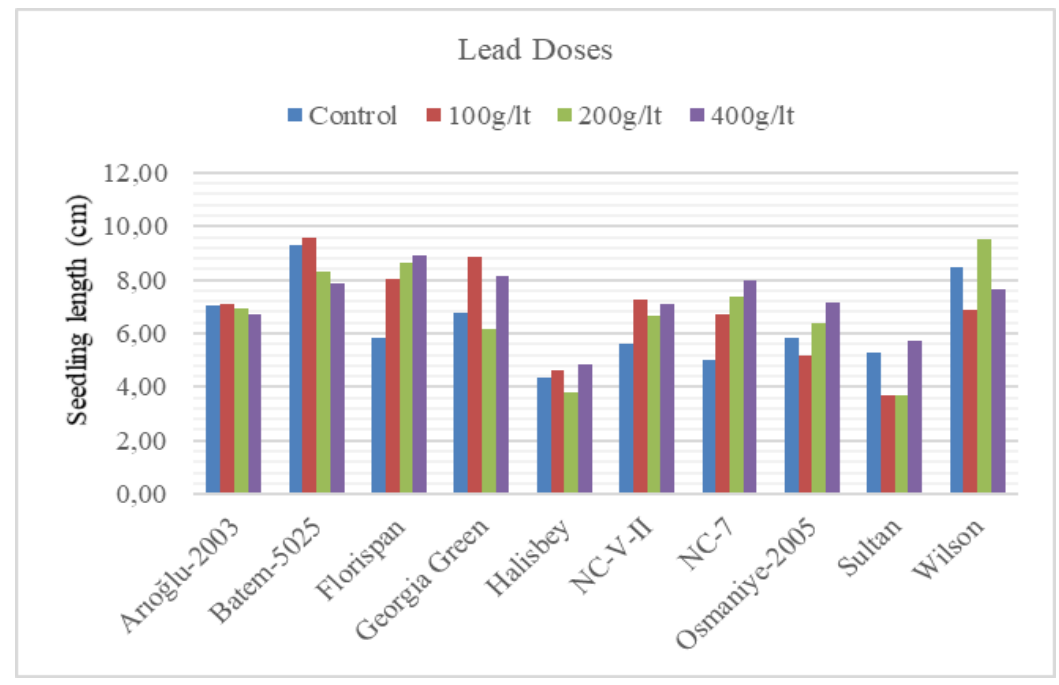

Figure 2. The interaction of Arachis hypogaea L. varieties' seedling length

\section{Radicle fresh weight $(g)$}

As indicated in Table 1, it was seen that there was a statistically significant $(\mathrm{P}<0.01)$ variation among varieties in terms of fresh weights of radicles. The highest radicle fresh weights were observed in Osmaniye-2005 (3.096 g) and NC-7 (2.913 g) varieties, while the lowest was seen in Georgia Green as $1.61 \mathrm{~g}$. Statistically $(\mathrm{P}<0.05)$ there were significant variations among lead doses in terms of their effect of radicle on age weights. The highest radicle fresh weight was seen at $400 \mathrm{mg} \mathrm{Pb}\left(\mathrm{NO}_{3}\right)_{2} \mathrm{~L}^{-1}$ dose as $2.442 \mathrm{~g}$, while the lowest $(2.032 \mathrm{~g})$ was seen at the control dose (Table 1). It was determined that the effects of variety and lead dose interaction on radicle fresh weights were statistically significant $(\mathrm{P}<0.01)$. The highest radicle fresh weight $(4.18 \mathrm{~g})$ was obtained from Osmaniye-2005 cultivar and $400 \mathrm{mg} \mathrm{Pb}\left(\mathrm{NO}_{3}\right)_{2} \mathrm{~L}^{-1}$ lead dose, while the lowest weights (1.408 and $1.400 \mathrm{~g}$ ) were detected from Georgia Green and Sultan at 200 and $100 \mathrm{mg} \mathrm{Pb}\left(\mathrm{NO}_{3}\right)_{2} \mathrm{~L}^{-1}$ doses (Table 1; Fig. 3).

\section{Plumule fresh weight (g)}

In terms of plumule fresh weight, when the varieties were examined, statistically significant $(\mathrm{P}<0.01)$ differences were found among the cultivars. The highest radicle 
fresh weight was observed in Sultan, NC-V-II and Osmaniye-2005 (26.672, 26.627 and $26.141 \mathrm{~g}$ ) varieties, respectively, while the lowest weights were observed in Florispan (12.675 g) and Georgia Green (14.480 g) varieties (Table 1). As seen in Table 1, it was determined that increasing lead doses produced significant $(\mathrm{P}<0.01)$ different effects on plumule fresh weight. The highest plumula fresh weights $(23.112$ and $22.563 \mathrm{~g}$ ) were observed at 400 and $200 \mathrm{mg} \mathrm{Pb}\left(\mathrm{NO}_{3}\right)_{2} \mathrm{~L}^{-1}$ lead doses, while the lowest weights $\left(2.67\right.$ and $21.04 \mathrm{~g}$ ) were determined at $100 \mathrm{mg} \mathrm{Pb}\left(\mathrm{NO}_{3}\right)_{2} \mathrm{~L}^{-1}$ and control treatments (Table 1). When the variety and lead dose interactions were examined in Table 1, it was observed that the effect interactions on plumula fresh weights were statistically very significant $(\mathrm{p}<0.01)$. The highest plumule fresh weights $(28.33,28.26$, and $28.32 \mathrm{~g}$, respectively) were observed from NC-V-II, Sultan and Wilson at 100 and $400 \mathrm{mg}$ of $\mathrm{Pb}\left(\mathrm{NO}_{3}\right)_{2} \mathrm{~L}^{-1}$ doses, while the lowest weights $(11.601$ and $12.011 \mathrm{~g})$ were weighed in Fluorescent and NC-7 varieties from control and $100 \mathrm{mg} \mathrm{Pb}\left(\mathrm{NO}_{3}\right)_{2} \mathrm{~L}^{-1}$ applications (Table 1; Fig. 4).

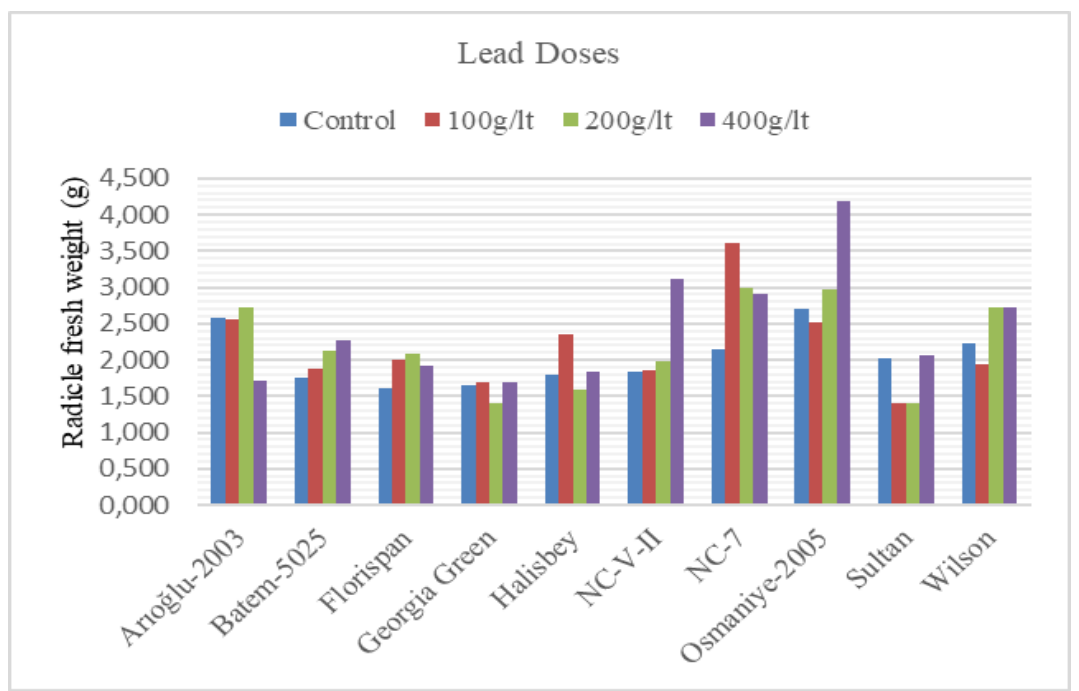

Figure 3. The interaction of Arachis hypogaea L. varieties' radicle fresh weight

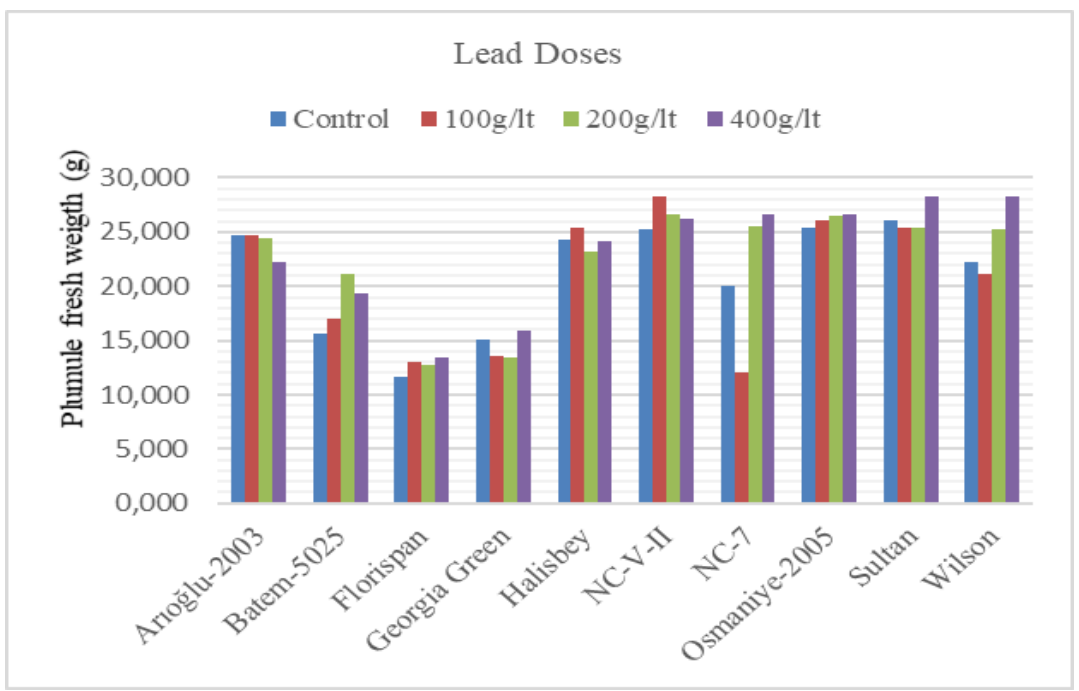

Figure 4. The interaction of Arachis hypogaea L. varieties' plumule fresh weight 


\section{Seedling fresh weight (g)}

As shown in Table 2, the differences among the varieties were found to be statistically significant $(\mathrm{P}<0.01)$. The highest seedling fresh weight $(29.237$ and $28.821 \mathrm{~g}$ ) was measured in Osmaniye-2005 and NC-V-II cultivars, while the lowest seedling fresh weights $(14.581,16.086$, and $20.267 \mathrm{~g}$, respectively) were seen in Florispan, Georgia Green and Batem-5025 cultivars, respectively. There was a statistically significant $(\mathrm{P}<0.01)$ variation among the lead doses in terms of their effects on seedling age weights. The highest seedling fresh weights (25.554 and $24.824 \mathrm{~g}$ ) were obtained from 400 and $200 \mathrm{mg} \mathrm{Pb}\left(\mathrm{NO}_{3}\right)_{2} \mathrm{~L}^{-1}$ lead doses, while the lowest seedling fresh weights (22.850 and $23.071 \mathrm{~g}$ ) were being observed in $100 \mathrm{mg} \mathrm{Pb}$ $\left(\mathrm{NO}_{3}\right)_{2} \mathrm{~L}^{-1}$ and control applications (Table 2). In terms of seedling fresh weights, interactions of varieties and doses have been observed to produce statistically $(p<0.01)$ significant variations. The average fresh weight value of seedlings most affected by stress conditions (13.212 g) was obtained from the control dose of Florispan variety (Table 2; Fig. 5).

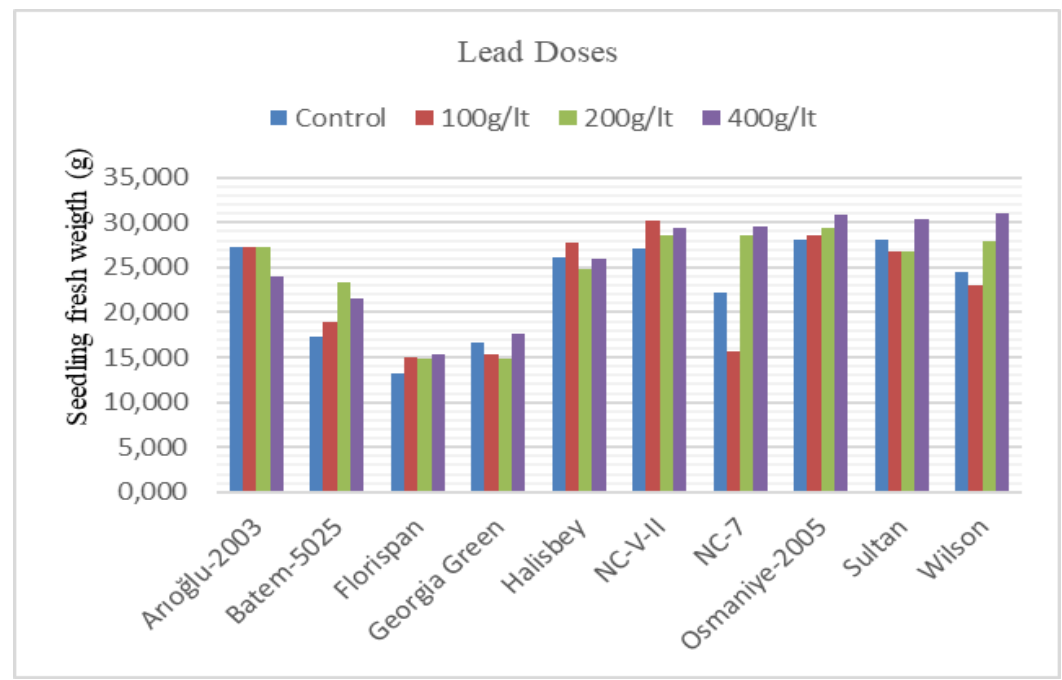

Figure 5. The interaction of Arachis hypogaea L. varieties' seedling fresh weight

\section{Radicle dry weight (g)}

When the averages of the dry weight of the radicles were examined from the results presented in Table 2, it was seen that there were statistically significant $(\mathrm{P}<0.01)$ variations among the varieties. The highest radicle dry weight was observed in Osmaniye-2005 variety as $0.549 \mathrm{~g}$, while the lowest dry weight was observed in Batem5025 variety as $0.373 \mathrm{~g}$. As a result of the analysis of variance, it was determined that lead doses were statistically significant $(\mathrm{p}<0.05)$ in terms of their effect on the dry weight of the radicle. The highest radicle dry weights $(0.476$ and $0.468 \mathrm{~g})$ were obtained from 400 and $200 \mathrm{mg} \mathrm{Pb}\left(\mathrm{NO}_{3}\right)_{2} \mathrm{~L}^{-1}$ doses, while the lowest weights $(0.420$ and $0.424 \mathrm{~g})$ were determined in the control and $100 \mathrm{mg} \mathrm{Pb}\left(\mathrm{NO}_{3}\right)_{2} \mathrm{~L}^{-1}$ applications (Table 2). When the binary interactions were examined in terms of the dry weight of the radicles, it was found that the variety $\mathrm{x}$ dose interactions showed statistically significant $(\mathrm{P}<0.01)$ variations. The highest radicle dry weight value was obtained from the dual combination of Osmaniye-2005 and $400 \mathrm{mg} \mathrm{Pb}\left(\mathrm{NO}_{3}\right)_{2} \mathrm{~L}^{-1}$ as $0.710 \mathrm{~g}$ (Table 2; Fig. 6). 
Table 2. The means and the LSD groups of SFW, RDW, PDW, SDW, SVI, GSN properties of Arachis hypogaea L. varieties

\begin{tabular}{|c|c|c|c|c|c|c|c|c|c|c|c|c|c|}
\hline Varieties & $\begin{array}{l}\text { Doses } \\
\left(\mathrm{g} \mathrm{L}^{-1}\right) \\
\end{array}$ & $\begin{array}{c}\text { SFW } \\
\text { (g) }\end{array}$ & $* ; * *$ & $\begin{array}{c}\text { RDW } \\
\text { (g) }\end{array}$ & $* ; * *$ & $\begin{array}{c}\text { PDW } \\
\text { (g) }\end{array}$ & $* *$ & $\begin{array}{c}\text { SDW } \\
(\mathrm{g})\end{array}$ & $* *$ & SVI & $* ; * *$ & $\begin{array}{c}\text { GSN } \\
\text { (number) }\end{array}$ & $* *$ \\
\hline \multirow{5}{*}{$\begin{array}{l}\text { Arığlu- } \\
2003\end{array}$} & Control & 27.32 & a-e & 0.451 & c-f & 10.85 & & 11.30 & & 688.8 & $\mathrm{kl}$ & 24.33 & \\
\hline & 100 & 27.33 & a-e & 0.430 & $c-f$ & 10.11 & & 10.54 & & 710.0 & $\mathrm{jk}$ & 25.00 & \\
\hline & 200 & 27.19 & a-e & 0.488 & $b-f$ & 10.19 & & 10.68 & & 681.0 & $\mathrm{kl}$ & 24.33 & \\
\hline & 400 & 23.95 & d-f & 0.307 & $\mathrm{f}$ & 8.84 & & 9.15 & & 636.1 & 1-n & 23.67 & \\
\hline & Mean & 26.45 & C & 0.419 & CDE & 10.00 & C & 10.42 & C & 679.0 & $\mathbf{E}$ & 24.33 & $\mathbf{A B}$ \\
\hline \multirow{5}{*}{$\begin{array}{l}\text { Batem- } \\
5025\end{array}$} & Control & 17.37 & g-i & 0.381 & d-f & 6.42 & & 6.80 & & 931.5 & $\mathrm{a}$ & 25.00 & \\
\hline & 100 & 18.86 & $f-h$ & 0.359 & ef & 6.43 & & 6.79 & & 953.0 & $\mathrm{a}$ & 25.00 & \\
\hline & 200 & 23.27 & ef & 0.389 & d-f & 8.03 & & 8.42 & & 830.0 & de & 25.00 & \\
\hline & 400 & 21.57 & e-g & 0.362 & ef & 6.64 & & 7.00 & & 785.7 & fg & 25.00 & \\
\hline & Mean & 20.27 & $\mathbf{E}$ & 0.373 & $\mathbf{E}$ & 6.88 & D & 7.25 & D & 875.0 & $\mathbf{A}$ & 25.00 & $\mathbf{A}$ \\
\hline \multirow{5}{*}{ Florispan } & Control & 13.21 & I & 0.356 & $\mathrm{f}$ & 5.39 & & 5.75 & & 561.0 & op & 24.00 & \\
\hline & 100 & 15.01 & hi & 0.504 & b-e & 5.22 & & 5.73 & & 806.3 & ef & 25.00 & \\
\hline & 200 & 14.78 & hi & 0.486 & $c-f$ & 4.95 & & 5.44 & & 850.6 & $\mathrm{~cd}$ & 24.67 & \\
\hline & 400 & 15.32 & hi & 0.499 & $b-f$ & 5.16 & & 5.66 & & 877.9 & $\mathrm{bc}$ & 24.67 & \\
\hline & Mean & \begin{tabular}{|l|}
14.58 \\
\end{tabular} & $\mathbf{F}$ & 0.461 & BC & 5.18 & $\mathbf{E}$ & 5.64 & $\mathbf{E}$ & 774.0 & C & 24.58 & $\mathbf{A B}$ \\
\hline \multirow{5}{*}{$\begin{array}{l}\text { Georgia } \\
\text { Green }\end{array}$} & Control & 16.67 & hi & 0.412 & d-f & 7.32 & & 7.73 & & 647.8 & $1-n$ & 23.67 & \\
\hline & 100 & 15.33 & hi & 0.390 & d-f & 6.71 & & 7.10 & & 885.8 & $\mathrm{~b}$ & 25.00 & \\
\hline & 200 & 14.79 & hi & 0.320 & $\mathrm{f}$ & 6.28 & & 6.60 & & 621.5 & $\mathrm{n}$ & 25.00 & \\
\hline & 400 & 17.56 & gh & 0.404 & d-f & 6.85 & & 7.26 & & 804.2 & ef & 24.67 & \\
\hline & Mean & 16.09 & $\mathbf{F}$ & 0.382 & DE & 6.79 & D & 7.17 & D & 739.8 & D & 24.58 & $\overline{A B}$ \\
\hline \multirow{5}{*}{ Halisbey } & Control & 26.11 & de & 0.511 & b-d & 12.26 & & 12.77 & & 426.9 & $\mathrm{u}$ & 24.67 & \\
\hline & 100 & 27.73 & $a-d$ & 0.463 & $c-f$ & 11.04 & & 11.50 & & 452.5 & st & 24.67 & \\
\hline & 200 & 24.80 & de & 0.437 & $c-f$ & 11.63 & & 12.07 & & 377.3 & $\mathrm{v}$ & 25.00 & \\
\hline & 400 & 26.02 & de & 0.515 & b-d & 11.97 & & 12.48 & & 484.7 & $\mathrm{r}$ & 25.00 & \\
\hline & Mean & 26.16 & $\mathbf{C}$ & 0.482 & ABC & 11.72 & B & 12.21 & B & 435.4 & I & 24.83 & $\mathbf{A B}$ \\
\hline \multirow{5}{*}{ NC-V-II } & Control & 27.11 & b-e & 0.379 & ef & 11.54 & & 11.92 & & 518.6 & $\mathrm{q}$ & 23.33 & \\
\hline & 100 & 30.18 & $\mathrm{a}$ & 0.493 & b-f & 11.86 & & 12.35 & & 715.5 & $\mathrm{jk}$ & 24.67 & \\
\hline & 200 & 28.60 & $a-d$ & 0.461 & $c-f$ & 11.88 & & 12.34 & & 633.6 & $\mathrm{mn}$ & 23.67 & \\
\hline & 400 & 29.39 & $\mathrm{a}-\mathrm{c}$ & 0.657 & $\mathrm{ab}$ & 11.59 & & 12.25 & & 712.1 & $\mathrm{jk}$ & 25.00 & \\
\hline & Mean & 28.82 & $\mathbf{A}$ & 0.498 & $\overline{A B}$ & 11.72 & B & 12.22 & B & 645.0 & $\mathbf{F}$ & 24.17 & $\overline{A B}$ \\
\hline \multirow{5}{*}{ NC-7 } & Control & 22.19 & ef & 0.332 & $\mathrm{f}$ & 11.34 & & 11.67 & & 431.7 & tu & 21.67 & \\
\hline & 100 & 15.61 & hi & 0.437 & $c-f$ & 11.38 & & 11.82 & & 651.7 & $\operatorname{lm}$ & 24.33 & \\
\hline & 200 & 28.51 & $a b$ & 0.564 & $\mathrm{bc}$ & 12.10 & & 12.66 & & 736.0 & $\mathrm{ij}$ & 25.00 & \\
\hline & 400 & 29.56 & $a-d$ & 0.433 & $c-f$ & 10.69 & & 11.12 & & 770.2 & gh & 24.00 & \\
\hline & Mean & 23.97 & D & 0.442 & BCD & 11.38 & B & 11.82 & B & 647.4 & $\mathbf{F}$ & 23.75 & B \\
\hline \multirow{5}{*}{$\begin{array}{l}\text { Osmaniye- } \\
2005\end{array}$} & Control & 28.07 & a-d & 0.461 & c-f & 12.29 & & 12.75 & & 460.7 & $\mathrm{~s}$ & 20.00 & \\
\hline & 100 & 28.64 & $a-d$ & 0.453 & $c-f$ & 13.09 & & 13.55 & & 471.4 & rs & 23.00 & \\
\hline & 200 & 29.42 & $\mathrm{a}$ & 0.572 & $\mathrm{bc}$ & 13.04 & & 13.61 & & 579.9 & o & 22.67 & \\
\hline & 400 & 30.81 & $a b$ & 0.710 & $\mathrm{a}$ & 12.19 & & 12.90 & & 627.2 & $\mathrm{n}$ & 22.00 & \\
\hline & Mean & 29.24 & $\mathbf{A}$ & 0.549 & $\mathbf{A}$ & 12.65 & $\mathbf{A}$ & 13.20 & $\mathbf{A}$ & 534.8 & gh & 21.92 & $\mathrm{C}$ \\
\hline \multirow{5}{*}{ Sultan } & Control & 28.12 & a-d & 0.442 & c-f & 13.11 & & 13.55 & & 526.5 & $\mathrm{q}$ & 25.00 & \\
\hline & 100 & 26.79 & c-e & 0.308 & $\mathrm{f}$ & 12.59 & & 12.90 & & 369.0 & $\mathrm{v}$ & 25.00 & \\
\hline & 200 & 28.96 & $a-d$ & 0.404 & $d-f$ & 14.75 & & 15.16 & & 537.4 & $\mathrm{pq}$ & 24.00 & \\
\hline & 400 & 30.31 & $\mathrm{a}$ & 0.412 & $\mathrm{~d}-\mathrm{f}$ & 12.94 & & 13.36 & & 562.3 & $\mathrm{o}$ & 24.67 & \\
\hline & Mean & 28.55 & $\mathbf{A B}$ & 0.391 & DE & 13.35 & $\mathbf{A}$ & 13.74 & $\mathbf{A}$ & 498.8 & $\mathbf{H}$ & 24.67 & $\overline{A B}$ \\
\hline \multirow{5}{*}{ Wilson } & Control & 24.53 & $\mathrm{de}$ & 0.474 & $c-f$ & 10.78 & & 11.26 & & 848.6 & $\mathrm{~d}$ & 25.00 & \\
\hline & 100 & 23.01 & ef & 0.404 & $d-f$ & 10.08 & & 10.49 & & 664.5 & 1 & 24.00 & \\
\hline & 200 & 27.93 & $a-d$ & 0.557 & $\mathrm{bc}$ & 11.76 & & 12.31 & & 924.3 & $\mathrm{a}$ & 24.33 & \\
\hline & 400 & 31.05 & $\mathrm{a}$ & 0.463 & $c-f$ & 11.60 & & 12.06 & & 752.0 & hi & 24.67 & \\
\hline & Mean & 26.63 & BC & 0.475 & BC & 11.06 & B & 11.53 & B & 797.4 & B & 24.50 & $\mathbf{A B}$ \\
\hline \multirow{4}{*}{\multicolumn{2}{|c|}{$\begin{array}{c}\operatorname{LSD}(0.05) \text { for } \mathrm{V} \\
\mathrm{LSD}(0.05) \text { for } \mathrm{LD} \\
\mathrm{LSD}(0.05) \text { for } \mathrm{V} \times \mathrm{LD} \\
\mathrm{CV}(\%)\end{array}$}} & 2.032 & & 0.069 & & 0.808 & & 0.821 & & 16.05 & & 1.12 & \\
\hline & & 1.285 & & 0.043 & & 0.511 & & 0.519 & & 10.15 & & 0.71 & \\
\hline & & 7.040 & & 0.238 & & 2.800 & & 2.844 & & 55.61 & & 3.86 & \\
\hline & & 10.386 & & 18.874 & & 9.871 & & 9.602 & & 2.98 & & 5.67 & \\
\hline
\end{tabular}

SFW: Seed Fresh Weight, RDW: Radicle Dry Weight, PDW: Plumule Dry Weight, SDW: Seed Dry Weight, SVI: Seedling Vigor Index, GSN: Germinated Seed Number, V: Varieties, LD: Lead doses

*The mean in the same column, expressed in lowercase and indicated with different letters, is statistically different from each other within the $\mathrm{P} \leq 0.05$ error limits according to LSD test

**The mean in the same column, expressed in capital and indicated with different letters, is statistically different from each other within the $\mathrm{P} \leq 0.05$ error limits according to LSD test 


\section{Plumule dry weight (g)}

As can be seen from Table 2, when the averages of plumule dry weights were examined, it was determined that there were very significant variations among the varieties as statistical $(\mathrm{P}<0.01)$, while differences between lead doses were found to be insignificant $(p>0.05)$ in terms of their effects on plumule dry weights. The highest plumule dry weights were seen in Sultan (13.349 g) and Osmaniye-2005 $(12.653 \mathrm{~g})$ cultivars, while the lowest plumule dry weight was seen in Florispan variety as $5.182 \mathrm{~g}$.

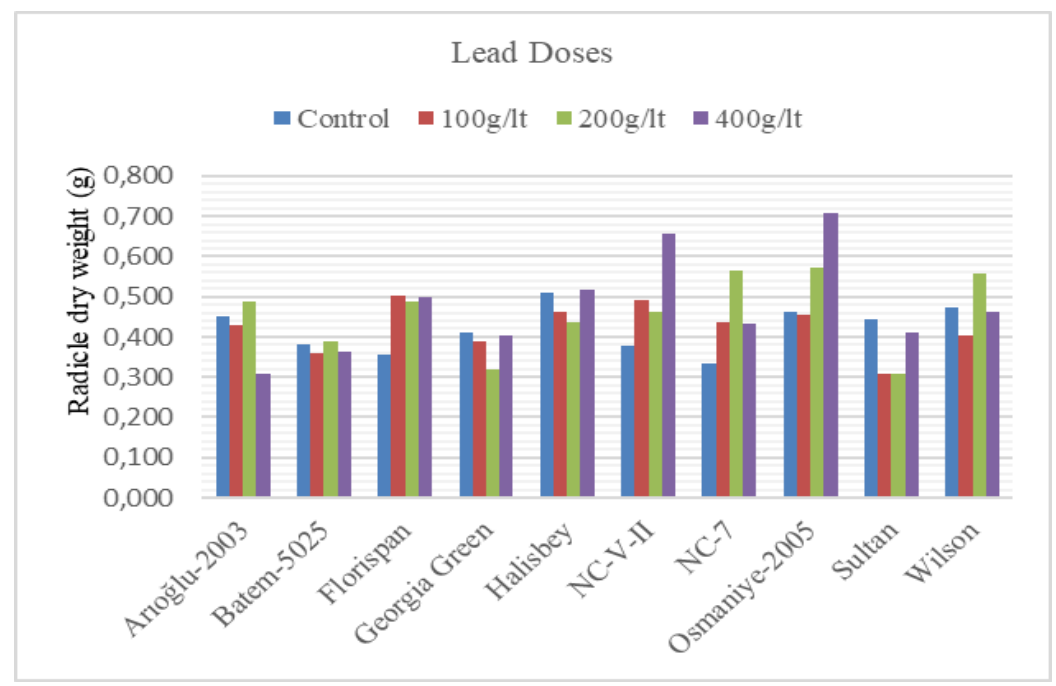

Figure 6. The interaction of Arachis hypogaea L. varieties' radicle dry weight

\section{Seedling dry weight (g)}

When the averages of seedling dry weights were examined from Table 2, it was found that there were statistically significant differences $(\mathrm{P}<0.01)$ among the varieties, whereas the differences in lead doses were statistically insignificant $(\mathrm{P}>0.05)$. The highest seedling dry weights were seen in Sultan (13.740 g) and Osmaniye-2005 $(13.202 \mathrm{~g})$ varieties, while the lowest seedling dry weight was seen in Florispan variety as $5.644 \mathrm{~g}$.

\section{Seedling vigor index}

When the averages of seedling vigor indices were examined from Table 2, it was found that the differences among the varieties and the differences among the lead doses were statistically significant $(\mathrm{P}<0.01)$. According to the results, Batem-5025 varieties had the highest seedling vigor index (875.05), while Halisbey varieties had the lowest seedling vigor index (435.37). The highest seedling vigor index (701.24) was detected at $400 \mathrm{mg} \mathrm{Pb}\left(\mathrm{NO}_{3}\right)_{2} \mathrm{~L}^{-1}$ lead dose, while the lowest seedling vigor index (604.27) was determined from the control application (Table 2). Due to the different reactions of the varieties to the lead doses, the effect of variety $\mathrm{x}$ dose interaction on seedling vigor indices was found to be statistically significant $(\mathrm{P}<0.01)$. It was determined that Sultan variety with the lowest tolerance to lead doses had lowest seedling vigor index (369.05) at $100 \mathrm{mg} \mathrm{Pb}\left(\mathrm{NO}_{3}\right)_{2} \mathrm{~L}^{-1}$, while Halisbey variety (377.33) was produced lowest seedling vigor index at $200 \mathrm{mg} \mathrm{Pb}\left(\mathrm{NO}_{3}\right)_{2} \mathrm{~L}-1$ dose (Table 2; Fig. 7). 


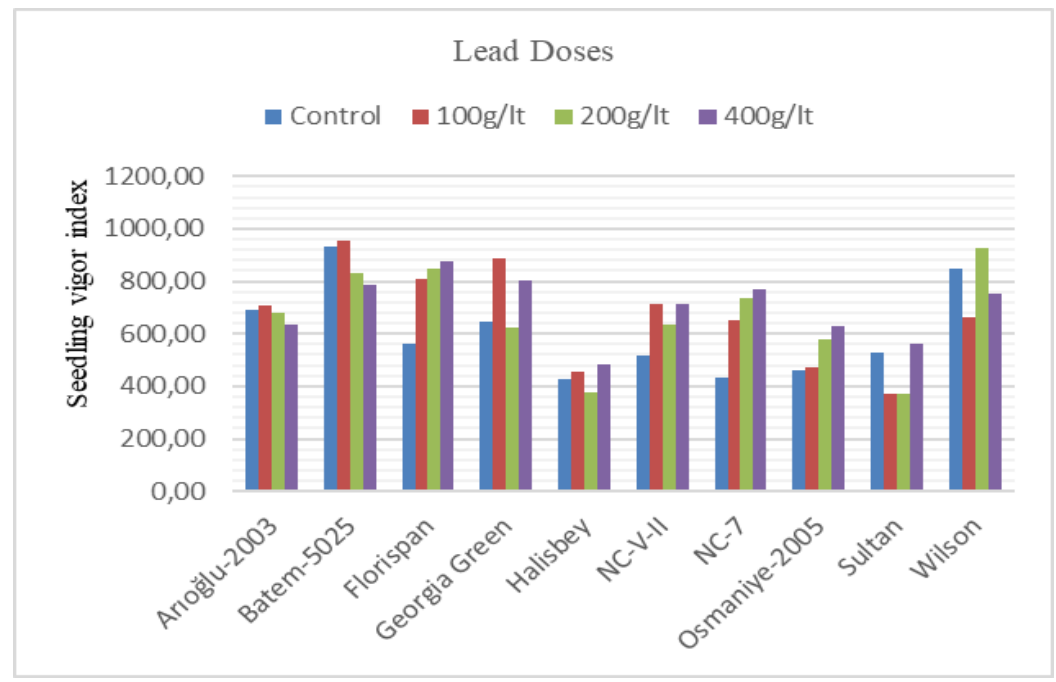

Figure 7. The interaction of Arachis hypogaea L. varieties' seedling vigor index

\section{Germinated seed number (number)}

In Table 2, when the average of germinated seed number, it was seen that there were significant variations $(\mathrm{P}<0.01)$ among the varieties and it was determined that the differences between lead doses were insignificant $(\mathrm{P}>0.05)$. The highest germinated seed number was observed in Batem-5025 cultivar as 25.00, while the lowest number was obtained in Osmaniye-2005 cultivar as 21.92.

\section{The relationships among the observed characteristics}

In the study, a correlation analysis was conducted to reveal the relationships between all investigated properties of peanut varieties subjected to lead concentrations, an abiotic stress factor. The correlations among the all investigated properties are thought to be significant $(\mathrm{P}<0.01$ and $\mathrm{P}<0.05)$ due to the widespread and complex lead interactions occurring in the plant organs of different cultivars (Table 3). As presented in Table 3, it was found that germination percentage, one of the most important attribute, had significant positive correlations $(r=0.689$ and $r=0.273)$ with the germination index and germinated seed number, but had significant negative correlations $(r=-0.233$ and $r=-$ 0.232 ) with germination seed dry weight and seedling vigor index. Table 3 can be examined for the positive and negative relationship among other characteristics.

\section{Discussion}

Germination is the first event in a plant's life and is started by the regulation of enzymatic reactions that activate catabolic and anabolic processes in storage tissues and on the embryonic axis, respectively (Lamhamdi et al., 2011). Germination will be prevented even if a single component of these processes is influenced. Therefore, it is of great concern because of the heavy metal toxicity in the surrounding area and the effects of the abiotic stress conditions on plant growth. Plants under stress conditions are likely to be negatively affected by high concentrations of heavy metals. One known explanation of the effect of heavy metals on plant physiology is that this results in a variety of nutritional disorders (Lamhamdi et al., 2011; Sengar et al., 2008). A high 
concentration of lead, one of the most abundant and ubiquitously distributed toxic pollutants (Sharma and Dubey, 2005), may lead to an inhibition in germination, root elongation, seedling development, plant growth, and more than (Sethy and Ghosh, 2013). Although the effect of $\mathrm{Pb}$ varies depending on concentration, soil type, soil properties, and plant species (Lakshmi, 2014), Pb toxicity causes a reduction of germination percentage, length and dry mass of roots and shoots (Munzuroglu and Geckil, 2002).

Table 3. Correlation table for observed parameters of Arachis hypogaea L. samples

\begin{tabular}{|c|c|c|c|c|c|c|c|c|c|c|c|c|c|c|c|}
\hline & GI & RL & PL & SL & RFW & PFW & SFW & RDW & & PDW & SDW & & SVI & & GSN \\
\hline GP & $0.689^{* *}$ & -0.172 & 0.163 & 0.072 & 0.164 & -0.171 & -0.130 & -0.145 & & -0.024 & -0.233 & $*$ & -0.232 & * & $0.273^{* *}$ \\
\hline GI & & $-0.820^{* *}$ & $0.450^{* *}$ & 0.173 & 0.442 & ${ }^{* * *}-0.126$ & -0.471 & ${ }^{* *}-0.465$ & ** & -0.080 & -0.576 & ** & -0.573 & $* *$ & $0.568^{* *}$ \\
\hline RL & & & $-0.479^{* *}$ & -0.192 * & -0.474 & ${ }^{* *} \quad 0.022$ & 0.510 & ** 0.489 & $* *$ & 0.078 & 0.578 & $* *$ & 0.575 & $* * *$ & $-0.537^{* * *}$ \\
\hline PL & & & & $0.234^{*}$ & 0.925 & ${ }^{* *} \quad 0.282$ & ${ }^{* *}-0.343$ & ** -0.293 & ** & 0.321 & ${ }^{* *}-0.449$ & $* *$ & -0.432 & ${ }^{* *}$ & $0.764^{* *}$ \\
\hline SL & & & & & 0.585 & ${ }^{* *} \quad 0.081$ & -0.005 & 0.006 & & 0.062 & -0.242 & $* *$ & -0.237 & $* *$ & $0.523^{* *}$ \\
\hline RFW & & & & & & 0.267 & ${ }^{* *}-0.288$ & ${ }^{* *}-0.242$ & ** & 0.292 & ${ }^{* *}-0.469$ & ** & -0.453 & ** & $0.841^{* *}$ \\
\hline PFW & & & & & & & 0.324 & ** 0.432 & ** & 0.703 & ${ }^{* *} \quad 0.328$ & ** & 0.352 & ** & 0.082 \\
\hline SFW & & & & & & & & 0.993 & ** & 0.289 & ${ }^{* *} \quad 0.827$ & ** & 0.829 & $* *$ & $-0.373^{* *}$ \\
\hline RDW & & & & & & & & & & 0.362 & ${ }^{* *} \quad 0.829$ & ** & 0.834 & $* *$ & $-0.345^{* *}$ \\
\hline PDW & & & & & & & & & & & 0.260 & ** & 0.296 & $* *$ & 0.091 \\
\hline SDW & & & & & & & & & & & & & 0.999 & ** & $-0.568^{* *}$ \\
\hline SVI & & & & & & & & & & & & & & & $-0.559^{* *}$ \\
\hline
\end{tabular}

In this study, the effect of increased lead doses on germination and seedling growth parameters were investigated. As seen in Tables 1, 2 and Figures 1-7, lead concentrations had statistically significant different effects on some observed attributes such as radicle length, seedling length, radicle fresh weight, plumule fresh weight, seedling fresh weight, radicle dry weight, and seedling vigor index in peanut varieties. Increased lead doses have been found to cause an increase in the properties studied in some varieties, while a decrease in others. It was determined that peanut varieties react differently to lead concentrations due to their different genotypic structures and that lead doses in some of them do not have any significant effect. In a few varieties' germinations and growth parameters observed were suppressed differentially at all lead treatments. In some varieties, many features have been found to be promoted differently in some lead treatments. Some previous studies have also reported ineffective or positive effects of lead doses up to a certain level on germination parameters in some plants Zaier et al. (2010), however, Pb has often been reported to have negative effects on most plant species (Hussain et al., 2013; Mishra and Choudhuri, 1998; Pourrut et al., 2011; Sethy and Ghosh, 2013). In the present study, as a result of the use of 10 different genotypic varieties of peanut, both positive and negative effects of $\mathrm{Pb}$ were determined on the varieties. Similar to the results determined in this study, Islam et al. (2007) reported that at higher concentrations, lead accelerates germination and also causes adverse effects on the length of the radicle and hypocotyl in Elsholtzia argyi. Additionally, the results were similar to those of (Xiong, 1998), who studied lead uptake and tolerance of Brassica pekinensis. Plant species vary in the level of tolerance to elements for growth but may cause excessive mineral toxicity. These differences can be attributed to variable ion translocation to plant organs. The results of the present 
findings appear to be a useful indicator for determining the toxic nature and tolerance indices of $\mathrm{Pb}$ in Arachis hypogaea. Plants differ in their tolerance level to metal stresses. This information can be considered to be a step that contributes to discovering and finding the tolerance limit of Arachis hypogaea in lead treatments at different concentrations.

\section{Conclusion}

Traditional breeding practices and methodologies of plants have not been successful in providing resistance to different biotic and abiotic stresses due to species restrictions in the natural system. As a result, considering that the germination percentages of some peanut varieties give the highest values, especially at $200 \mathrm{mg} \mathrm{L}^{-1}$ lead dose. But, Batem5025 variety was found to be the most tolerant variety against lead poisoning in terms of germination rate, germination index and importantly seedling vigor index. It is thought that peanut varieties have different mechanisms at the cell level and that these plants work simultaneously with multiple mechanisms, and that further investigation is needed to reveal clearer $\mathrm{Pb}$ tolerance and hyperaccumulation. Likewise, among the peanut varieties that have been taken into the test, other breeding studies should be carried out for varieties that show the most resistance to lead toxicity.

\section{REFERENCES}

[1] Abdul-Baki, A. A., Anderson, J. D. (1973): Vigor determination in soybean seed by multiple criteria. - Crop Science 13(6): 630-633.

[2] AOSA (Association of Official Seed Analysts) (1984): Rules for testing seeds. - Journal of Seed Technology 6: 1-125.

[3] Ertekin, E. N., Ertekin, İ., Bilgen, M. (2020): Effects of some heavy metals on germination and seedling growth of sorghum. - KSU Journal of Agriculture and Nature 23(6): 1608-1615. DOI: 10.18016/ksutarimdoga.v23i54846.722592.

[4] Hussain, A., Abbas, N., Arshad, F., Akram, M., Khan, Z. I., Ahmad, K., ... Mirzaei, F. (2013): Effects of diverse doses of lead $(\mathrm{Pb})$ on different growth attributes of Zea mays $\mathrm{L}$. - Agricultural Sciences 4(5): 262. DOI: https://doi.org/10.4236/as.2013.45037.

[5] Islam, E., Yang, X., Li, T., Liu, D., Jin, X., Meng, F. (2007): Effect of Pb toxicity on root morphology, physiology and ultrastructure in the two ecotypes of Elsholtzia argyi. Journal of Hazardous Materials 147(3): 806-816. DOI: https://doi.org/10.1016/j.jhazmat.2007.01.117.

[6] Kadiroğlu, A. (2008): Yerfistığı yetiştiriciliği. - Batı Akdeniz Tarımsal Araştırma Enstitüsü Müdürlüğü, Antalya.

[7] Konlan, S., Sarkodie-Addo, J., Asare, E., Adu-Dapaah, H., Kombiok, M. J. (2013): Groundnut (Arachis hypogaea L.) Varietal response to spacing in the humid forest zone of Ghana. - ARPN Journal of Agricultural and Biological Science 8(9): 642-651.

[8] Kumar, A., Prasad, M., Sytar, O. (2012): Lead toxicity, defense strategies and associated indicative biomarkers in Talinum triangulare grown hydroponically. - Chemosphere 89(9): 1056-1065.

[9] Lakshmi, N. (2014): Effect of lead $(\mathrm{Pb}+2)$ on seed germination of sesamum (Sesamum indicum L. Var ylm-11) in solution and pot cultures at different test concentrations of lead. - Journal of Agricultural and Biological Science 9(5): 172-177. http://www.arpnjournals.com/jabs/volume_05_2014.htm. 
[10] Lamhamdi, M., Bakrim, A., Aarab, A., Lafont, R., Sayah, F. (2011): Lead phytotoxicity on wheat (Triticum aestivum L.) seed germination and seedlings growth. - Comptes Rendus Biologies 334(2): 118-126. DOI: https://doi.org/10.1016/j.crvi.2010.12.006.

[11] Maguire, J. D. (1962): Speed of germination - aid in selection and evaluation for seedling emergence and vigor. - Crop Science 2(2): 176-177.

[12] Mani, A., Sankaranarayanan, K. (2018): Heavy Metal and Mineral Element-Induced Abiotic Stress in Rice Plant. - In: Shah, F. (ed.) Rice Crop: Current Developments. IntechOpen, London.

[13] Mishra, A., Choudhuri, M. (1998): Amelioration of lead and mercury effects on germination and rice seedling growth by antioxidants. - Biologia Plantarum 41(3): 469473.

[14] Munzuroglu, O., Geckil, H. (2002): Effects of metals on seed germination, root elongation, and coleoptile and hypocotyl growth in Triticum aestivum and Cucumis sativus. - Archives of Environmental Contamination and Toxicology 43(2): 203-213. DOI: http://dx.doi.org/10.1007/s00244-002-1116-4.

[15] Onaga, G., Wydra, K. (2016): Advances in Plant Tolerance to Abiotic Stresses. - In: Abdurakhmonov, I. Y. (ed.) Plant Genomics. IntechOpen, London, pp. 229-272.

[16] Pourrut, B., Shahid, M., Dumat, C., Winterton, P., Pinelli, E. (2011): Lead uptake, toxicity, and detoxification in plants. - Rev Environ Contam Toxicol 213:113-136. DOI: 10.1007/978-1-4419-9860-6_4.

[17] Sengar, R. S., Gautam, M., Sengar, R. S., Garg, S. K., Sengar, K., Chaudhary, R. (2008): Lead stress effects on physiobiochemical activities of higher plants. - Rev Environ Contam Toxicol 196: 73-93. DOI: 10.1007/978-0-387-78444-1_3.

[18] Sethy, S. K., Ghosh, S. (2013): Effect of heavy metals on germination of seeds. - Journal of Natural Science, Biology, and Medicine 4(2): 272-275. DOI: https://doi.org/10.4103/0976-9668.116964.

[19] Sharma, K. K., Bhatnagar-Mathur, P. (2006): Peanut (Arachis hypogaea L.). - In: Wang, K. (ed.) Agrobacterium Protocols. Humana Press, Totowa, NJ, pp. 347-358.

[20] Sharma, P., Dubey, R. S. (2005): Lead toxicity in plants. - Brazilian Journal of Plant Physiology 17(1): 35-52. http://www.scielo.br/pdf/\%0D/bjpp/v17n1/a04v17n1.pdf.

[21] Xiong, Z.-T. (1998): Lead uptake and effects on seed germination and plant growth in a $\mathrm{Pb}$ hyperaccumulator Brassica pekinensis Rupr. - Bulletin of Environmental Contamination and Toxicology 60(2): 285-291.

[22] Zaier, H., Ghnaya, T., Rejeb, K. B., Lakhdar, A., Rejeb, S., Jemal, F. (2010): Effects of EDTA on phytoextraction of heavy metals $(\mathrm{Zn}, \mathrm{Mn}$ and $\mathrm{Pb}$ ) from sludge-amended soil with Brassica napus. - Bioresource Technology 101(11): 3978-3983. DOI: https://doi.org/10.1016/j.biortech. 2010.01.035. 